\title{
COLORADOSCHOOLOFMINES
}

EARTH•ENERGY•ENVIRONMENT

Division of ECONOMICS AND BUSINESS

WORKING PAPER SERIES

\section{Determining the Success of Carbon Capture and Storage Projects}

Dominique Thronicker Ian Lange

Working Paper 2014-14

http://econbus . mines . edu/working-papers/wp201414.pdf

Colorado School of Mines

Division of Economics and Business

1500 Illinois Street

Golden, CO 80401

December 2014

(C) 2014 by the listed authors. All rights reserved. 
Colorado School of Mines

Division of Economics and Business

Working Paper No. 2014-14

December 2014

Title:

Determining the Success of

Carbon Capture and Storage Projects*

Author(s):

Dominique Thronicker

Division of Economics

University of Stirling

Stirling, FK9 4LA

UK

Dominique.thronicker@stir.ac.uk

Ian Lange

Division of Economics and Business

Colorado School of Mines

Golden, CO 80401-1887

ilange@mines . edu

\begin{abstract}
Carbon Capture and Storage (CCS) is regarded as one of the most important technologies to mitigate climate change while providing fossil-fuel based energy security. During the past decade, projects in support of the development and deployment of the technology have been initiated across the globe. However, a considerable number of these projects have later been put on hold or cancelled. Currently, there is little understanding of what characteristics may have led to these undesirable outcomes. Using data on planned, cancelled and operational CCS projects to date, this paper aims to elicit technological, economic and policy characteristics that render CCS projects more or less likely to become operational. The results consistently find that confirmation of storage site and capture processes that are pre-combustion, industrial separation, or natural gas separation increase the probability of project success, while presence of a carbon policy and non-commercial storage of $\mathrm{CO} 2$ are negatively linked to project success.
\end{abstract}

\title{
$J E L$ classifications: L51, Q5, H3
}

Keywords: Carbon Capture and Storage; Regression Analysis; Carbon Policy; Technological Change.

\footnotetext{
* The authors wish to thank Pete Maniloff, Frans de Vries, and seminar participants at the 2014 CESifo Energy and Climate Economics Network conference and the 2014 Scottish Institute for Research in Economics Energy and Environmental Economics workshop for their helpful comments.
} 


\section{Introduction}

Carbon Capture and Storage (CCS) is widely considered an important component of a low-carbon technology portfolio to mitigate against climate change at least cost (IEA 2013; IPCC 2007; Edenhofer et al, 2010). Despite much effort into the development and demonstration of the technology in recent years, the number of CCS projects that are currently operational has fallen short of the "[...] breadth and depth [necessary] to allow it to play its full part" (The Global CCS Institute, 2013:15). Globally, over a quarter of CCS projects, including "vanguard projects" (Stigson et al., 2012), have been postponed, put on hold or cancelled altogether. A lack of economic viability of CCS is often suggested as the main reason behind these project halts. However, since there are also successfully operational CCS projects, the question arises whether there are systemic characteristics that render some CCS projects more likely to become operational while others are more likely to fail. The answer might disclose important lessons for future CCS deployment. To the authors' knowledge no quantitative analysis of characteristics of operational and failed CCS projects has yet been conducted. It is the objective of this paper to fill this research gap in order to address the above question.

We use a unique dataset that combines project information from various online CCS databases and contains all integrated CCS projects attempted globally, irrespective of sector, size or project outcome. Technical, economic, and policy factors are used to determine whether they exhibit a positive or negative impact on successful project completion. Given the small number of projects, a number of empirical specifications are used. We find relatively consistent effects for a number of explanatory variables. First, identification of the carbon dioxide $\left(\mathrm{CO}_{2}\right)$ storage site as part of the planning process is significantly correlated to likelihood of project success. The specific storage site characteristics are relevant in so far as saline reservoirs are negatively linked to project success compared to enhanced oil and gas reservoirs, probably due to the lack of commercial benefit of $\mathrm{CO}_{2}$ storage in saline reservoirs. These results confirm the Stigson et al. (2012) finding that storage solutions are crucial for facilitating a viable business case for CCS. Second, capture technologies post- and oxyfuel combustion are less likely to succeed than pre-combustion, natural gas processing or industrial separation capture processes. This result is in contrast with Stigson et al. (2012) who find no differences in the success of projects with pre-, post- or oxyfuel combustion capture technologies. Third, we find that CCS projects located in areas with an explicit carbon price is negatively correlated to CCS project success. This result is surprising initially but considering that other abatement options (fuel switching, improved efficiency) tend to be cheaper and the fact that a carbon price might lead firms to initially consider a CCS project (before ultimately deciding against it) the result can be explained. Fourth, we find that public funding and previous experience is not positively related to likelihood of project success. A possible explanation for this result is that governments might look for marginally profitable investments to subsidize (allowing the private sector to finance projects expected to be profitable) or the potential for adverse selection in which projects are put forward by firms for public funding. However, we lack detailed funding data to fully explore which explanation fits better. As for the experience result, it has been shown that less experienced investors are more likely to continue projects after it is clear they are unprofitable relative to experienced investors (Fennema and Perkins, 2008).

These results provide suggestions for policymakers looking to encourage implementation of CCS. Public policy instruments are usually focussing on financial support to reduce the construction cost burden to industry. Most important appears therefore the finding that storage site selection, despite 
usually being considered to only account for a small part of the overall CCS upfront costs, is vital for project success ${ }^{1}$. This finding is in line with Stigson et al. (2012) and the IEA (2013), who state that "[...] identifying suitable storage capacity [...] is perhaps the largest challenge associated with CCS [requiring] publicly funded [...] pre-competitive exploration" (ibid: 30). This call for an enhanced role of government activity can further be supported by the finding that non-commercial storage of $\mathrm{CO}_{2}$ and public funding are negatively linked to project success. From an investor's point of view, high cost, low risk options for technology investment are likely to be favourable to slightly lower cost investments with underlying high risks. Cook (2009) found in an analysis of CCS deployment in Australia that "[...] both industry and governments have found it difficult at times to match their risk profile requirements, which has slowed progress [...] reluctance of governments to assume liability slowed deployment". Likewise, Emhjellen and Osmundsen (2014) highlight the "high political risk" (ibid: 4) underlying carbon policy to which projects with long pay-back times, like CCS, are particularly vulnerable. Thus, policy instruments in support of lowering the upfront investment costs alone might not be proving effective. Storage site identification and liability, as well as long-term policy uncertainties account at least for some of the underlying risk related to CCS. Our results provide an argument for at least a critical review of existing funding policy and possibly a re-think of public ownership of non-commercial storage sites.

The remainder of the paper provides background on the state of CCS knowledge, an overview of the data used and explanation of the analysis, followed by a detailed discussion of the results, including robustness analysis findings.

\section{Background}

CCS comprises a set of technologies that facilitate the capture of $\mathrm{CO}_{2}$ emissions at various large point sources, and the transport of the captured $\mathrm{CO}_{2}$ to a geological sequestration site where it is stored indefinitely. CCS applications at power plants are regarded as the most important technology to mitigate climate change while providing fossil-fuel based energy security. Moreover, CCS is considered the only technology capable to achieve large cuts in industrial sector emissions (IEA, 2012). There is some experience of the successful application of CCS in the oil and gas industry, but the integrated large-scale deployment of CCS in the power sector is a novel technology proven only at pilot plant stage.

The high capital intensity of large-scale CCS deployment paired with high technology risk are believed to be the main constraints to the technology's deployment (Lohwasser and Madlener, 2012; Stigson et al., 2012; Van Alphen et al., 2009). It is argued that CCS demonstration projects are heavily reliant on government support to prevent the technology from falling into the "valley of death", where the funding gap at commercialisation stage is too large to be surmounted (De Coninck et al, 2008; Ghosh and Nanda, 2010). Watson et al. (2014) state that "[...] not all demonstrations are likely to perform as expected, systematic learning and evaluation [...] of this package of support will [therefore] be essential" (ibid: 203). Additionally, "[f]eedbacks from the deployment [...] process may help in the refinement of the technology or the development of the next generation" (Sagar and Van der Zwaan,

\footnotetext{
${ }^{1}$ Two main reasons for lack of a storage site when a project is announced are public opposition to the storage of a "pollutant", $\mathrm{CO}_{2}$, near their homes and unresolved long-term liability in case of leakage from the site.
} 
2006: 2607). The results of this analysis suggest that government support is not a sufficient condition to CCS deployment.

However, government support might be needed in order to encourage firms to undertake investments which may provide benefits to the industry as a whole through learning. Empirical research tailored towards feedbacks at this very early stage of CCS deployment might give insights into the effectiveness of investment in diverse CCS technologies as opposed to increased specialization. For instance, Watson et al. (2014) find that while "[m]any analysts think that pre-combustion technology is potentially more efficient, elegant and cheaper [...] there is a lack of empirical evidence on whether post- or pre-combustion CCS will be more economically attractive" (ibid: 196). We argue that analysing successful and failed CCS demonstration projects can provide some guidance to answer such and similar questions. The analysis in this paper is conducted in line of this reasoning and with the intention to contribute to ensure that limited resources are spent effectively.

Technological change towards low-carbon energy technologies and the optimal policy instruments to support this change has been discussed in the economic literature without a clear consensus (Sorrel and Sijm, 2003). This is in part due to the fact that different low-carbon technologies are associated with different challenges for deployment and diffusion (Stephens et al., 2008; Winskel et al., 2014). Stephens et al. (2008) therefore highlight the need for empirical research of deployment of specific emerging technologies in and across different states to gain insights to barriers and opportunities of deployment. In the case of CCS, this empirical research of deployment is often conducted via innovation system approaches (Van Alphen et al., 2009; Van Alphen et al., 2010) as well as qualitative approaches based on stakeholder and expert views (Johnsson et al., 2010) and some modelling studies largely based on learning curve scenarios (Lohwasser and Madlener, 2012). Additionally a small number of studies use historical technological analogues to extrapolate insights for CCS deployment (Van den Bergh, 2013; Rubin, 2007). The main reason for the lack of more quantitative analyses are significant data limitations, especially with regards to reliable CCS cost data (Markusson and Chalmers, 2013). For this reason as well as the limited number of projects and their large-scale, learning curve studies in particular are difficult to undertake in the context of CCS deployment.

To the authors' knowledge, there are very few research papers that specifically analyse CCS demonstration projects conducted to date. Most notable is one study by Stigson et al. (2012) using a qualitative survey approach via expert interviews to identify lessons learned from failed CCS projects. They consider only seven selected postponed or cancelled CCS projects and find discrepancies between governments' CCS policies and firms' deployment considerations as well as a lack of financial incentives to be the key obstacle to project success. They also find that experts favour no CCS capture technology over another and consider storage solutions crucial for facilitating a viable business case for CCS. Another descriptive study by the Global CCS Institute (2013) provides a helpful overview of all ongoing, planned as well as cancelled projects, tabulated by a large number of categories such as project location, project type, capture technology, storage site, etc. Emhjellen and Osmundsen (2013) analysed the return on investment from CCS projects and found that they are generally lower than expected. This combined with the relatively large rate of returns that oil companies require contribute to the lack of successful CCS projects. While the CCS Institute (2013) and Emhjellen and Osmundsen (2013) look at some case studies more in-depth, they do not conduct a structured analysis of factors leading to project success or failure. 


\section{Data}

Information from a number of publicly available sources were used to compile the dataset utilized in this analysis. One main source is the MIT CCS project database ${ }^{2}$, which contains information on operational CCS power and non-power plant projects, as well as on announced, planned, cancelled and inactive projects. Two other main sources are the CCS project databases of ZeroCO2 ${ }^{3}$ and of the Global CCS Institute ${ }^{4}$. Where the latest project update was older than January 2014 or where data was missing, an online search for most recent information on each project was conducted, so that all information in the dataset of this analysis is valid as of January 2014.

Due to this update, there are some differences between the available online databases and the dataset of this analysis ${ }^{5}$. Additionally, the total number of CCS projects between the datasets differs. Because of the objective of this analysis, not all CCS related projects listed on the online databases are included. Only those projects were of interest that demonstrate the whole CCS chain of capture, transportation and storage, while projects that exclusively concentrate on either $\mathrm{CO} 2$ capture or storage were omitted. Such projects in the online databases usually refer to research activities into technological feasibility or efficiency improvements of the capture process or monitoring techniques at the storage stage and are thus part of the invention stage of CCS technology. As these are in their nature quite different from integrated deployment projects they are not considered relevant for this analysis. However, there is no limitation to the type or size of CCS project in the dataset. Thus, also very small and specified industrial CCS deployment projects are included that do not appear in all of the online databases.

The dataset compiles information on the status of each project as well as some technical and economic specifics. We use eleven predominantly categorical variables to predict the likelihood of project success. The variation in project success through the inclusion of cancelled and inactive projects allows for an unbiased estimation of the determinants of success or failure. Table 1 summarizes the dataset and explanatory variables.

"Size" is the only continuous variable in the dataset and refers to the amount of $\mathrm{CO}_{2}$ in Mt per year that the CCS project is designed to capture and store. The "public funding" dummy is a binary variable indicating whether the project received any kind of public funding support. This could be a direct subsidy, a tax credit or any other instrument or mix of instruments. The "storage site confirmed" dummy indicates whether the specific storage site where the captured $\mathrm{CO}_{2}$ is intended to be deposited was decided upon during the planning stage. The "pilot project" dummy indicates whether the project was planned as a small pilot as opposed to a large-scale demonstration. The "previous CCS experience" dummy indicates whether the project was preceded by a pilot project or, alternatively, whether the project owner has previously been involved in conducting any other CCS project. The remaining variables are categorical. The "storage" variable refers to the type of subterranean reservoir envisaged by the project for the final sequestration of $\mathrm{CO}_{2}$. The "capture process" variable indicates the type of $\mathrm{CO}_{2}$ capture process utilised to capture the $\mathrm{CO}_{2}$ at the emissions source. "Feedstock" is a dummy variable indicating the type of fossil fuel input from which the $\mathrm{CO} 2$ emissions originate. "Industry" is a

\footnotetext{
${ }^{2}$ http://sequestration.mit.edu/tools/projects/index database.html

3 http://www.zeroco2.no/projects/list-projects/

4 http://www.globalccsinstitute.com/projects/browse

${ }^{5}$ Dataset available by request from the authors
} 
dummy variable indicating which sector the CCS project is deployed. The "region" variable refers to the location of the CCS project, and is included to test whether the different technology policy frameworks deployed in different regions have any effect on the project success. ${ }^{6}$ Based on the region a project is based in, a "carbon policy" dummy is created which takes the value of one for projects in Europe, Alberta, British Columbia, or Norway and is zero otherwise. Each of these entities had an explicit price on carbon, either through a tax or tradable permit scheme before 2012 when most of the projects in the sample were announced.

For most variables there exists a considerable amount of missing data points due to a lack of publicly available project information. This lack of information is particularly pronounced for the relating investment costs, which would be a crucial variable to include in the analysis. The CCS cost data that is available is often not reliable (see also Markusson \& Chalmers, 2013). Even where cost data is considered reliable, it is often not clear how to disentangle CCS unit costs from other plant investment costs. This is particularly difficult for new built plants that incorporate a CCS unit. Attempts were made to include an investment cost variable and a variable indicating the share of public funding towards the investment cost in the analyses, however the sample size is too small for any reliable inferences to be made. Therefore, the cost variable and the share of public funding variable have not been included in the analyses presented here. ${ }^{7}$

The missing data, combined with the relatively small number of CCS projects overall, means that the model needs to be parsimonious with respect to the degrees of freedom in the regression. With this in mind, three variables, "alliance of firms", "onshore", and "retrofit", are not included in the results presented here. Alliance is a dummy variable that indicates whether the project is undertaken by a cooperation between several firms as opposed to a single firm. Onshore is a dummy variable that indicates whether the $\mathrm{CO} 2$ would be sequestered onshore as opposed to offshore. Retrofit is a dummy variable that indicates whether the CCS project is attached to an existing facility as oppose to being integrated into a new-built plant. All of these variables are statistically insignificant in all of our models and their inclusion does not alter the sign or significance of the other variables. Additionally, there is a high level of collinearity between the industry and feedstock variables. The models analysed will include the feedstock variables and omit the industry variables. Results for the other variables are unchanged when including one versus the other. Results are available by request from the authors.

The present analysis does not include a time parameter, nor does it explicitly consider the carbon price at different points in time when project decisions about final investment or cancellation were made. The analysis does also not consider other price effects, such as the cost of construction materials, labour or input resources. Implications of these omissions are considered in the discussion of results.

\section{Methodology}

\footnotetext{
${ }^{6}$ Estimating the model with alternative aggregation and disaggregation of the regions compared to the base model specification yields no change from the results shown. These results are available from the authors by request.

${ }^{7}$ Given the interest in how these variables alter the likelihood of project success, a short discussion of the estimates are given here. The investment cost variable typically has a negative sign, as expected, but is not statistically different than zero. The share of public funding is not statistically significant also. Results are available by request from the authors.
} 
The dataset contains information on CCS projects in different project development stages. Namely a project is in one of five possible stages: operational, under construction, being planned, on hold, or cancelled. We argue that these stages can conceptually be ordered from the most to the least desirable project status. Therefore, an ordered probit regression model is used to estimate whether the explanatory variables relating to certain project characteristics increase or decrease the likelihood of a CCS project to be in a more desirable stage. Operational projects are referred to in this paper as 'successful', unless otherwise stated.

The ordered probit (oprobit) base model is:

$y_{i}^{*}=\beta_{0}+T_{i} \beta_{1}+E_{i} \beta_{2}+P_{i} \beta_{3}+\varepsilon_{i}$

where $\mathrm{y}_{\mathrm{i}}^{*}$ is the project status. $\mathrm{y}_{\mathrm{i}}^{*}=\{0,1,2,3,4\}$ with the following order:

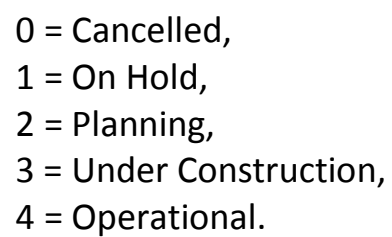

The integers 0 to 4 have no meaning in terms of their value and merely describe the ordering from least to the most desirable project status. $T_{i}$ describes the set technological variables, $E_{i}$ the economic variables, $\mathrm{P}_{\mathrm{i}}$ the policy variables and $\varepsilon_{\mathrm{i}}$ is an idiosyncratic error term. To reiterate the research interest of this paper, the analysis aims to establish whether there are systemic characteristics that render some CCS projects more likely to be successful (4) while others might lead more likely to project failure (0). Size, storage, capture process, feedstock are considered in terms of their technological characteristics of the CCS project. Storage site confirmed, storage type, and previous CCS experience are variables to distinguish economic project characteristics ${ }^{8}$. And finally, public funding and carbon policy are used as policy related characteristics of a CCS project.

The base model is estimated on the main sample as well as a sample excluding pilot plant projects, as these might bias the estimation in so far as pilots tend to be short term projects deployed with the intend of technological learning rather than $\mathrm{CO}_{2}$ emissions mitigation per se. The model is also estimated for the power sector only as these are projects are generally larger and of great policy interest. All models are run with robust standard errors.

It might be argued that the outcomes $\mathrm{y}_{\mathrm{i}}{ }^{*}$ are not necessarily strictly speaking ordinal or that the main outcomes of interest are 'success' or 'failure' of a project. The dependent variable, $\mathrm{y}_{\mathrm{i}}{ }^{*}$, could be respecified to two possible outcomes, $0=$ failure and $1=$ success. A complication occurs as projects currently listed as in planning do not have a logical place in the success or failure dichotomous specification. An estimation removing the planning projects is undertaken, however the number of observations is relatively small. For increased understanding of the determinants of CCS success, two

\footnotetext{
${ }^{8}$ The original dataset also included a dummy variable on whether the project had managed to secure sufficient investment. This variable had to be dropped from the analysis as it was highly positively correlated with the outcome variable, i.e. projects that that had secured what was considered sufficient investment were significantly more likely to be successful. Since the expectation of economic viability of a project is a precondition for investment, this is hardly a surprising correlation. We still find it interesting to mention as it reaffirms the findings of other (non-quantitative) studies mentioned in the introduction that economic viability is key to project success.
} 
forms of the dichotomous dependent variable are created. An optimistic dichotomous dependent variable will define 'failure' as projects on hold or cancelled and 'success' as projects in the planning, construction and operational stage. A pessimistic dichotomous dependent variable will define 'failure' as projects planned, on hold or cancelled and 'success' as projects in the construction or operational stage. Comparing the results with these two types of dichotomous dependent variables will reveal which characteristics are strongly associated with success or failure. ${ }^{9}$ The two dichotomous outcome variable specifications are estimated using a linear probability model (LPM) both including and excluding pilot plants from the sample for the same reason as explained above.

\section{Results}

Table 2 shows the ordered probit marginal effects for the operational and cancelled including and excluding the pilot plant observations. Interpretation is based on the direction of the effect, i.e. whether a change compared to the base value increases or decreases the likelihood of the outcome, rather than size of the effect given the sample size concerns discussed above.

The results consistently find that storage site confirmed statistically improves the likelihood of project success while public funding, being located in an area with a carbon price, and previous CCS experience statistically reduces the likelihood of project success. The coefficients and statistical significance of the two size variables imply a non-linear relationship between project success and size. The coefficients imply that as size increases, the chance of project success decreases at a decreasing rate. The size that would minimize the chance of success, given the coefficients, is larger than any size in our sample, implying a convex relationship between size and chance of success. The storage of $\mathrm{CO}_{2}$ in saline formations, compared to enhanced oil recovery (EOR), is detrimental to project success while the capture of $\mathrm{CO}_{2}$ by pre-combustion, industrial separation or natural gas processing, compared to postcombustion capture, is advantageous to project success. We also find CCS at oil-fuelled plants to be more likely to be successful when compared to coal feedstock. When excluding pilot projects from the observations, gas feedstock becomes less likely to be success compared to coal.

Our findings have been confirmed across these specifications. Finally, we re-estimated the base model for power plant CCS projects only. As these are often in the centre of policy debate around CCS as a mitigation option, it appeared interesting to analyse whether there are any determinants for project success or failure that are specific to power plant applications of CCS. The results of this model specification are consistent with the base model and can be found in Table 3.

The results of the alternative analysis using a LPM for a binary outcome variable specification are shown in Table 4. Significant effects found are consistent with the oprobit model. Storage site confirmation is significantly positive for all model specifications. Size again shows a convex relationship to chance of success. Carbon policy is significantly negative. Also consistent with the base model, natural gas processing and industrial separation are is significantly positively related to project

\footnotetext{
${ }^{9}$ An additional benefit of estimating the model with these two specifications of a dichotomous dependent variable is to reveal the potential impacts that the small sample size has on the results. Estimation results using small sample sizes are sensitive to changes, given that the estimates are means, when new information is added.
} 
success likelihood when compared to post-combustion across model specifications. Industry dummies are again not significant.

\section{Discussion}

The results are consistent across most model specifications. Our main finding is a significant positive effect of the decision for a storage site during the planning stage on the probability of CCS project success. This result makes intuitive sense as storage is an integral part of the CCS chain. Noticeably, out of the 108 observations in the dataset compiled for this analysis, 49 projects had not decided on an actual $\mathrm{CO}_{2}$ storage site. Since the dataset only contains projects that intended to demonstrate the whole CCS chain, this appears surprising. The analysis did not include any data on why a storage site was not decided upon. Globally, storage capacity is considered abundant and storage costs make up only a small fraction of the overall CCS project costs. But storage site identification and long-term monitoring regulations are challenging. Additionally, where $\mathrm{CO}_{2}$ is intended to be stored onshore and in highly populated areas, public acceptance of CCS might depict a formidable challenge though our analysis did not find a statistically significant impact of onshore storage sites. If a plant operator had no solution where to store the $\mathrm{CO}_{2}$ captured, it might have depicted a main factor to a potential lack of feasibility of the project and one important contribution to its increased likelihood to fail. In sum, this finding provides an important learning for future project design: Until a storage solution is found, investing in the planning and construction of a capture technology might not be economically efficient.

A second finding is that CCS projects which intend to store the captured $\mathrm{CO}_{2}$ in sites that have no private benefit of storage are less likely to become operational. This result is also intuitively sound and it can be assumed that for reasons of economic viability, project planners will aim at deriving private benefits from storing $\mathrm{CO}_{2}$. Since this is not always possible and saline reservoirs account for by far the largest share of geological storage capacity, whether it is economically efficient to plan and construct a capture technology where there's only saline storage capacity available is questionable. Especially where the location of the storage site coincides with the above mentioned acceptance issues or where there's opportunity cost to using this storage capacity due to alternative use potential. The latter aspects have not been analysed in this paper and might be interesting for future research.

In contradiction to our expectation is the result that previous experience with CCS projects is negatively related to the probability of project success. This effect is enhanced when pilot projects are excluded from the observations. Pilot projects usually lack previous experience as their main purpose is technological learning, yet they are usually successful, as they are very small scale. This strengthens the finding that for larger-scale projects experience with CCS projects is negatively related to the probability of project success. This finding might be explained with an observation from the private equity industry that more experienced investors are more willing to put on hold or abandon projects when they are deemed unprofitable ${ }^{10}$, while less experienced investors tend to hold on to projects longer. Many of the firms that invest in CCS projects are large oil, gas or utilities companies and their global suppliers. Most of them have previous experience with CCS and are simultaneously involved in a number of projects globally. Investment behaviour in line with the private equity industry, i.e. a

\footnotetext{
${ }^{10}$ In the private equity industry, an investor might invest in 10 projects initially, but carry on to the end only 3 of them as he more information through the projects' lifetime, leaving a larger share of projects on hold or cancelled by experienced investors.
} 
willingness to put projects on hold or cancel them and focus on selected more promising alternative projects, appears a plausible explanation for the finding.

The effect of public funding on project success is also negative, though not significant in all specifications. One reason for this finding might be that public funding goes, among others, towards large-scale projects that are more risky and struggle to find sufficient private investment since they do not present the economic viability private investors would look for. For those projects, it would have been interesting to analyse the effect of the share of public funding as part of the overall investment costs, but unfortunately the cost data available to the authors was insufficient to conduct that analysis.

Also negative for project success is the effect of the existence of a carbon policy. The introduction or existence of a carbon policy might suffice to incentivise firms' interest in potential CCS projects that might not have emerged otherwise. Thus, firms might engage in the planning of CCS projects before ultimately deciding against it considering that other abatement options (fuel switching, improved efficiency) tend to be cheaper options. This would be in line with the widely agreed fact that the carbon price levels of recent years are unlikely to be sufficient to deploy CCS technology successfully (Hamilton et al., 2009). Table 5 depicts a selection of cancelled CCS projects in locations that have a carbon policy in place and states the reason for cancellation. Most arguments given are financial, suggesting that the profitability of CCS project did not evolve as expected.

In most model specifications post- and oxyfuel capture technologies are significantly less likely to lead to CCS project success compared to pre-combustion, natural gas and industrial separation technologies. This result might support recent policy recommendations (e.g. von Hirschhausen et al., 2012) to enhance the focus of CCS deployment to include more industrial sector applications of CCS. The finding that capture of $\mathrm{CO}_{2}$ by pre-combustion is advantageous to project success compared to post-combustion capture is of particular interest as it delivers the empirical evidence that was lacking hitherto to support the expert assumption that pre-combustion capture technology might be preferable to post-combustion capture (Watson et al., 2014).

In terms of the effect of size on project success we find a consistent higher probability of success at small size with a decreasing at an increasing rate chance of success as size increases. These results are consistent even when we exclude pilot projects from the sample and confirm our expectation.

Other costs, such as the carbon price level, fuel prices or material costs are also completely omitted in the present analysis. The cost at the point in time when an investment or cancellation decision for a CCS project is made or the expectation of their future development might be crucial to control for in the analysis. However, it is neither always clear, exactly when the decision to invest or to put a project on hold was made nor is there much information of future price expectations of firms. Nonetheless, an empirical analysis of the correlation between various price levels and the decision to invest in or cancel a CCS project would be interesting, but is beyond the scope of this paper.

\section{Conclusion}

The objective of this paper is to identify the characteristics that render individual CCS projects more or less likely to become successfully operational. Using an ordered probit estimation as a base model, 
we analyse empirical data on projects in five different stages of development: planning, under construction, operational, on hold and cancelled. We find significant effects for a number of project characteristics. The findings are largely consistent across base model specifications as well as alternative specifications using a binary dependent variable. Most importantly, we find that a decision on a storage site where the captured $\mathrm{CO}_{2}$ will be sequestered has a consistent positive effect on project success likelihood. Further main results are that project experience, non-commercial storage of $\mathrm{CO}_{2}$, public funding and carbon policy are negatively linked to project success likelihood. Precombustion capture and CCS capture technologies generally applied in the industrial sector (natural gas processing and industrial separation) as well as projects of small scale are positively linked to success.

To our knowledge, this is the first regression analysis of existing or attempted CCS projects. The main contribution of this research is the empirical confirmation of CCS deployment barriers identified in the general CCS literature, which were largely gained through expert opinion surveys and innovation systems approaches. The findings of this analysis are also largely in line with the only other empirical analysis of existing CCS projects known to the authors by Stigson et al. (2012). Unfortunately, the analysis is limited by a lack of available and reliable cost data for the existing projects.

The success or failure of the development and deployment of any large integrated project on the scale such as CCS technology will always depend on many factors that are often unique to the specific project. The insights gained from the analysis of the limited number of attempted projects to date can therefore only be regarded crudely indicative. Nonetheless, the authors believe the analysis offers useful insights from which a number of policy implications can be inferred.

Firstly, in view of the consistency of the storage site confirmation variable, it appears advisable that any CCS project support without a definite solution for a storage site should be reviewed by policy makers with regards to its efficiency. The empirical data reveals a large share of projects being conducted without a storage solution that often end up being put on hold or being cancelled. Secondly, the finding that public funding is either non-significant or even has a significantly negative effect on project success likelihood is worrisome from an efficiency point of view. It can be inferred that financial support of a large-scale demonstration project alone is not sufficient.

\section{References}

Cook, P. J. (2009). Demonstration and Deployment of Carbon Dioxide Capture and Storage in Australia. Energy Procedia, 1(1), 3859-3866. doi:10.1016/j.egypro.2009.02.188

De Coninck, H., Stephens, J. C., \& Metz, B. (2009). Global learning on carbon capture and storage: A call for strong international cooperation on CCS demonstration. Energy Policy, 37(6), 2161-2165. doi:10.1016/j.enpol.2009.01.020

Edenhofer, O., Knopf, B., Barker, T., Baumstark, L., Bellevrat, E., Chateau, B., Criqui, P., Isaac, M., Kitous, A., Kypreos, S., Leimbach, M., Lessmann, K., Magne, B., Scrieciu, S., Turton, H. and van Vuuren, D. P., (2010). The Economics of Low Stabilization. Model Comparison of Mitigation Strategies and Costs, The Energy Journal 31, 11-48. doi:10.5547/ISSN0195-6574-EJ-Vol31-NoSI-2 
Emhjellen, M. and P. Osmundsen (2013). Rate of Return Requirement for Climate Versus Petroleum Projects. SPE Economics and Management, 5(2), 1-6. doi:10.2118/165932-PA

Emhjellen, M. and P. Osmundsen (2014). CCS: Failing to Pass Decision Gates. CESifo Working Paper No. 4944, accessed at https://ideas.repec.org/p/ces/ceswps/_4525.html.

Fennema, M. and J. Perkins. (2008). Mental budgeting versus marginal decision making: training, experience and justification effects on decisions involving sunk costs. Journal of Behavioural Decision Making, 21(3), 225-239. doi: 10.1002/bdm.585

Ghosh, S., and Nanda, R., (2010). Venture Capital Investment in the Clean Energy Sector, Harvard Business School, Working Paper 11-020, accessed at http://www.hbs.edu/faculty/Publication\%20Files/11-020.pdf

Hamilton, M. R., Herzog, H. J., \& Parsons, J. E. (2009). Cost and U.S. public policy for new coal power plants with carbon capture and sequestration. Energy Procedia, 1(1), 4487-4494.

doi:10.1016/j.egypro.2009.02.266

IEA (International Energy Agency) (2013). Energy Technology Perspectives: Technology Roadmap. Carbon Capture and Storage, accessed at https://www.iea.org/publications/freepublications/publication/TechnologyRoadmapCarbonCapture andStorage.pdf

IEA (International Energy Agency) (2012). A policy strategy for carbon capture and storage, accessed at http://www.iea.org/publications/freepublications/publication/policy_strategy_for_ccs.pdf

IPCC (Intergovernmental Panel on Climate Change) (2007), Fourth Assessment Report of the IPCC, Working Group III, IPCC, Cambridge University Press, Cambridge, UK.

Johnsson, F., Reiner, D., Itaoka, K., \& Herzog, H. (2010). Stakeholder attitudes on Carbon Capture and Storage-An international comparison. International Journal of Greenhouse Gas Control, 4(2), 410418. doi:10.1016/j.jiggc.2009.09.006

Lohwasser, R., \& Madlener, R. (2012). Economics of CCS for coal plants: Impact of investment costs and efficiency on market diffusion in Europe. Energy Economics, 34(3), 850-863. doi:10.1016/j.eneco.2011.07.030

Markusson, N., \& Chalmers, H. (2013). Characterising CCS learning: The role of quantitative methods and alternative approaches. Technological Forecasting and Social Change, 80(7), 1409-1417. doi:10.1016/j.techfore.2011.12.010

Rubin, E. S., Yeh, S., Antes, M., Berkenpas, M., \& Davison, J. (2007). Use of experience curves to estimate the future cost of power plants with $\mathrm{CO} 2$ capture. International Journal of Greenhouse Gas Control, 1(2), 188-197. doi:10.1016/S1750-5836(07)00016-3

Sagar, A. D., \& van der Zwaan, B. (2006). Technological innovation in the energy sector: R\&D, deployment, and learning-by-doing. Energy Policy, 34(17), 2601-2608. doi:10.1016/j.enpol.2005.04.012 
Sorrell, S., \& Sijm, J. (2003). Carbon trading in the policy mix. Oxford Review of Economic Policy, 420437.

Stephens, J. C., Wilson, E. J., \& Peterson, T. R. (2008). Socio-Political Evaluation of Energy Deployment (SPEED): An integrated research framework analyzing energy technology deployment. Technological Forecasting and Social Change, 75(8), 1224-1246. doi:10.1016/j.techfore.2007.12.003

Stigson, P., Hansson, A., \& Lind, M. (2012). Obstacles for CCS deployment: an analysis of discrepancies of perceptions. Mitigation and Adaptation Strategies for Global Change, 17(6), 601619. doi:10.1007/s11027-011-9353-3

The Global CCS Institute (2013). The Global Status of CCS, accessed at http://cdn.globalccsinstitute.com/sites/default/files/publications/116211/global-status-ccs-2013.pdf

Van Alphen, K., Noothout, P. M., Hekkert, M. P., \& Turkenburg, W. C. (2010). Evaluating the development of carbon capture and storage technologies in the United States. Renewable and Sustainable Energy Reviews, 14(3), 971-986. doi:10.1016/j.rser.2009.10.028

Van Alphen, K., Hekkert, M. P., \& Turkenburg, W. C. (2009). Comparing the development and deployment of carbon capture and storage technologies in Norway, the Netherlands, Australia, Canada and the United States-An innovation system perspective. Energy Procedia, 1(1), 4591-4599. doi:10.1016/j.egypro.2009.02.279

Van den Bergh, J. C. J. M. (2013). Environmental and climate innovation: Limitations, policies and prices. Technological Forecasting and Social Change, 80(1), 11-23. doi:10.1016/j.techfore.2012.08.004

Von Hirschhausen, C., Herold, J., Pao-yu, O., Haftendorn, C., (2012). CCTS-Technologie ein Fehlschlag: Umdenken in der Energiewende notwendig, DIW-Wochenbericht (0012-1304) 79(6), 3-9 accessed at http://hdl.handle.net/10419/58090

Watson, J., Kern, F., \& Markusson, N. (2014). Resolving or managing uncertainties for carbon capture and storage: Lessons from historical analogues. Technological Forecasting and Social Change, 81, 192204. doi:10.1016/j.techfore.2013.04.016

Winskel, M., Markusson, N., Jeffrey, H., Candelise, C., Dutton, G., Howarth, P., ... Ward, D. (2014). Learning pathways for energy supply technologies: Bridging between innovation studies and learning rates. Technological Forecasting and Social Change, 81, 96-114. doi:10.1016/j.techfore.2012.10.0 
Table 1: Summary Statistics

\begin{tabular}{|c|c|c|c|c|c|c|c|}
\hline & $\begin{array}{l}\text { All Data } \\
\mathrm{N}=108\end{array}$ & $\begin{array}{l}\text { Estimation } \\
\text { Sample } \\
N=66\end{array}$ & $\begin{array}{l}\text { Cancelled } \\
\text { (Status=0) } \\
\mathrm{N}=7\end{array}$ & $\begin{array}{l}\text { On Hold } \\
\text { (Status=1) } \\
\mathrm{N}=8\end{array}$ & $\begin{array}{l}\text { Planning } \\
\text { (Status=2) } \\
\mathrm{N}=27\end{array}$ & $\begin{array}{l}\text { Constr- } \\
\text { uction } \\
\text { (Status =3) } \\
\mathrm{N}=6\end{array}$ & $\begin{array}{l}\text { Operational } \\
\text { (Status=4) } \\
\mathrm{N}=18\end{array}$ \\
\hline Variable & Mean (S.D.) & Mean (S.D.) & Mean (S.D.) & Mean (S.D.) & Mean (S.D.) & Mean (S.D.) & Mean (S.D.) \\
\hline $\begin{array}{l}\text { Project Status (Ordinal; Larger Number= } \\
\text { Further Along) }\end{array}$ & $\begin{array}{l}2.24 \\
(1.42)\end{array}$ & $\begin{array}{l}2.30 \\
(1.28)\end{array}$ & & & & & \\
\hline Size (Million Tons/Year & $1.35(1.61)$ & $1.43(1.22)$ & $1.57(0.35)$ & $1.40(0.81)$ & $1.94(1.42)$ & $1.68(1.37)$ & $0.56(0.72)$ \\
\hline Public Funding Dummy & $0.79(0.41)$ & $0.81(0.38)$ & $0.85(0.38)$ & $0.88(0.35)$ & $0.73(0.45)$ & 1 & $0.83(0.38)$ \\
\hline Storage Site Confirmed & $0.59(0.49)$ & $0.68(0.46)$ & $0.14(0.38)$ & $0.50(0.53)$ & $0.66(0.48)$ & $0.83(0.38)$ & $0.95(0.23)$ \\
\hline Carbon Policy & $0.45(0.49)$ & $0.54(0.50)$ & $0.71(0.48)$ & $0.75(0.46)$ & $0.59(0.50)$ & $0.16(0.42)$ & $0.44(0.51)$ \\
\hline Alliance of Firms & $0.70(0.45)$ & $0.73(0.44)$ & $0.85(0.37)$ & $0.62(0.51)$ & $0.81(0.40)$ & 1 & $0.55(0.51)$ \\
\hline Pilot Project & $0.24(0.43)$ & $0.16(0.38)$ & & $0.12(0.35)$ & $0.07(0.26)$ & & $0.44(0.51)$ \\
\hline Previous CCS experience & $0.60(0.49)$ & $0.71(0.45)$ & 1 & $0.62(0.51)$ & $0.77(0.42)$ & 1 & $0.44(0.50)$ \\
\hline \multicolumn{8}{|l|}{ Storage } \\
\hline Enhance Oil Recovery/Commerical & $0.48(0.50)$ & $0.35(0.48)$ & & $0.25(0.46)$ & $0.37(0.42)$ & $0.50(0.54)$ & $0.44(0.51)$ \\
\hline Saline & $0.36(0.48)$ & $0.50(0.50)$ & $0.85(0.37)$ & $0.75(0.46)$ & $0.44(0.50)$ & $0.50(0.54)$ & $0.33(0.48)$ \\
\hline Depleted Oil/Gas Reservioir & $0.14(0.35)$ & $0.15(0.36)$ & $0.15(0.37)$ & & $0.18(0.40)$ & & $0.23(0.45)$ \\
\hline \multicolumn{8}{|l|}{ Capture Process } \\
\hline Post-Combustion & $0.45(0.49)$ & $0.39(0.49)$ & $0.71(0.48)$ & $0.62(0.51)$ & $0.37(0.49)$ & $0.16(0.40)$ & $0.27(0.46)$ \\
\hline Pre-Combustion & $0.27(0.44)$ & $0.27(0.44)$ & $0.14(0.37)$ & $0.25(0.46)$ & $0.40(0.50)$ & $0.33(0.51)$ & $0.11(0.32)$ \\
\hline Oxygen & $0.12(0.33)$ & $0.15(0.36)$ & $0.14(0.37)$ & $0.12(0.35)$ & $0.15(0.36)$ & & $0.22(0.42)$ \\
\hline Industrial Seperation & $0.09(0.28)$ & $0.12(0.33)$ & & & $0.07(0.26)$ & $0.16(0.40)$ & $0.27(0.46)$ \\
\hline Natural Gas Processing & $0.05(0.28)$ & $0.06(0.24)$ & & & & $0.33(0.51)$ & $0.11(0.32)$ \\
\hline \multicolumn{8}{|l|}{ Industry } \\
\hline Power & $0.67(0.47)$ & $0.63(0.48)$ & $0.85(0.37)$ & 1 & $0.74(0.45)$ & $0.33(0.51)$ & $0.33(0.48)$ \\
\hline Oil and Gas & $0.16(0.37)$ & $0.21(0.41)$ & $0.14(0.37)$ & & $0.07(0.26)$ & $0.50(0.54)$ & $0.44(0.51)$ \\
\hline Chemical & $0.10(0.30)$ & $0.08(0.26)$ & & & $0.07(0.26)$ & & $0.17(0.38)$ \\
\hline Other & $0.06(0.23)$ & $0.08(0.26)$ & & & $0.11(0.32)$ & $0.17(0.40)$ & $0.05(0.24)$ \\
\hline \multicolumn{8}{|l|}{ Region } \\
\hline USA & $0.25(0.43)$ & $0.25(0.44)$ & $0.14(0.37)$ & $0.25(0.46)$ & $0.25(0.44)$ & $0.16(0.40)$ & $0.33(0.48)$ \\
\hline Canada & $0.09(0.28)$ & $0.10(0.31)$ & $0.14(0.37)$ & $0.12(0.35)$ & $0.04(0.20)$ & $0.33(0.51)$ & $0.11(0.32)$ \\
\hline EU & $0.30(0.45)$ & $0.35(0.48)$ & $0.42(0.53)$ & $0.37(0.51)$ & $0.48(0.50)$ & & $0.22(0.42)$ \\
\hline Norway & $0.06(0.23)$ & $0.10(0.28)$ & $0.14(0.37)$ & $0.12(0.35)$ & $0.04(0.20)$ & & $0.16(0.38)$ \\
\hline Rest of World & $0.19(0.39)$ & $0.20(0.40)$ & $0.14(0.37)$ & $0.12(0.35)$ & $0.18(0.40)$ & $0.50(0.54)$ & $0.16(0.38)$ \\
\hline \multicolumn{8}{|l|}{ Feedstock } \\
\hline Coal & $0.64(0.48)$ & $0.60(0.50)$ & $0.72(0.45)$ & $0.75(0.46)$ & $0.74(0.44)$ & $0.50(0.54)$ & $0.33(0.50)$ \\
\hline Gas & $0.19(0.39)$ & $0.25(0.44)$ & $0.28(0.48)$ & $0.25(0.46)$ & $0.18(0.40)$ & $0.16(0.40)$ & $0.38(0.50)$ \\
\hline Oil & $0.03(0.18)$ & $0.01(0.12)$ & & & & & $0.05(0.23)$ \\
\hline Other & $0.13(0.34)$ & $0.12(0.32)$ & & & $0.07(0.26)$ & $0.33(0.51)$ & $0.22(0.42)$ \\
\hline
\end{tabular}


Table 2: Ordered Probit Marginal Effects

\begin{tabular}{|c|c|c|c|c|}
\hline Sample & \multicolumn{2}{|c|}{ All } & \multicolumn{2}{|c|}{ No Pilots } \\
\hline Status & Operational & Cancelled & Operational & Cancelled \\
\hline Variable & $\begin{array}{l}\text { Coefficient } \\
\text { (S.E.) }\end{array}$ & $\begin{array}{l}\text { Coefficient } \\
\text { (S.E.) }\end{array}$ & $\begin{array}{l}\text { Coefficient } \\
\text { (S.E.) }\end{array}$ & $\begin{array}{l}\text { Coefficient } \\
\text { (S.E.) }\end{array}$ \\
\hline Size & \begin{tabular}{|l}
$0.18^{* * *}$ \\
$(0.05)$
\end{tabular} & $\begin{array}{l}0.10^{* * *} \\
(0.04)\end{array}$ & \begin{tabular}{|l|}
$-0.08^{* *}$ \\
$(0.04)$
\end{tabular} & \begin{tabular}{|l|}
$0.07^{* * *}$ \\
$(0.03)$
\end{tabular} \\
\hline Size Squared & $\begin{array}{l}0.03^{* * *} \\
(0.01)\end{array}$ & $\begin{array}{l}-0.02 * * * \\
(0.007)\end{array}$ & $\begin{array}{l}0.01 \\
(0.01)\end{array}$ & \begin{tabular}{|l}
-0.01 \\
$(0.01)$
\end{tabular} \\
\hline Public Funding Dummy & \begin{tabular}{|l}
$-0.15^{* *}$ \\
$(0.05)$
\end{tabular} & \begin{tabular}{|l}
$0.09 * * *$ \\
$(0.03)$
\end{tabular} & $\begin{array}{l}0.11^{* * *} \\
(0.04)\end{array}$ & $\begin{array}{l}0.08^{* *} \\
(0.04)\end{array}$ \\
\hline Storage Site Confirmed & $\begin{array}{l}0.29 * * * \\
(0.06)\end{array}$ & $\begin{array}{l}-0.17^{* * *} \\
(0.03)\end{array}$ & $\begin{array}{l}0.25^{* * *} \\
(0.06)\end{array}$ & $\begin{array}{l}-0.20^{* * *} \\
(0.05)\end{array}$ \\
\hline Carbon Policy & \begin{tabular}{|l}
$-0.12 * * *$ \\
$(0.04)$
\end{tabular} & $\begin{array}{l}0.06^{* *} \\
(0.03)\end{array}$ & \begin{tabular}{|l}
$-0.10^{* *}$ \\
$(0.04)$
\end{tabular} & $\begin{array}{l}0.08 * * \\
(0.04)\end{array}$ \\
\hline Previous CCS Experience & $\begin{array}{l}-0.23^{* * *} \\
(0.07)\end{array}$ & \begin{tabular}{|l|}
$0.14^{* * *}$ \\
$(0.04)$
\end{tabular} & \begin{tabular}{|l}
$-0.14^{* *}$ \\
$(0.06)$
\end{tabular} & $\begin{array}{l}0.11^{* * *} \\
(0.05)\end{array}$ \\
\hline \multicolumn{5}{|c|}{ Storage Dummies (Reference=Enhance Oil Recovery/Commerical) } \\
\hline Saline & $\begin{array}{l}-0.12^{* * *} \\
(0.04)\end{array}$ & $\begin{array}{l}0.07^{* * *} \\
(0.03)\end{array}$ & \begin{tabular}{|l}
$-0.10 * *$ \\
$(0.05)$
\end{tabular} & $\begin{array}{l}0.08^{* *} \\
(0.04)\end{array}$ \\
\hline Depleted Oil/Gas Reservoir & $\begin{array}{l}0.07 \\
(0.06)\end{array}$ & $\begin{array}{l}-0.04 \\
(0.03)\end{array}$ & $\begin{array}{l}0.03 \\
(0.05)\end{array}$ & $\begin{array}{l}-0.03 \\
(0.04)\end{array}$ \\
\hline \multicolumn{5}{|c|}{ Capture Process Dummies (Reference=Post-Combustion) } \\
\hline Pre-Combustion & $\begin{array}{l}0.16^{* * *} \\
(0.06)\end{array}$ & $\begin{array}{l}-0.09 * * * \\
(0.04)\end{array}$ & $\begin{array}{l}0.15^{* * *} \\
(0.05)\end{array}$ & $\begin{array}{l}-0.13^{* * *} \\
(0.04)\end{array}$ \\
\hline Oxygen & \begin{tabular}{|l|}
-0.01 \\
$(0.09)$
\end{tabular} & $\begin{array}{l}0.01 \\
(0.05)\end{array}$ & $\begin{array}{l}0.06 \\
(0.06)\end{array}$ & $\begin{array}{l}-0.05 \\
(0.05)\end{array}$ \\
\hline Industrial Seperation & \begin{tabular}{|l|}
$0.36^{* * *}$ \\
$(0.10)$
\end{tabular} & $\begin{array}{l}-0.21^{* * *} \\
(0.06)\end{array}$ & $\begin{array}{l}0.34^{* * *} \\
(0.09)\end{array}$ & $\begin{array}{l}-0.28^{* * *} \\
(0.08)\end{array}$ \\
\hline NG Processing & \begin{tabular}{|l|}
$0.50^{* * *}$ \\
$(0.08)$
\end{tabular} & $\begin{array}{l}-0.29 * * * \\
(0.06)\end{array}$ & $\begin{array}{l}0.45^{* * *} \\
(0.08)\end{array}$ & $\begin{array}{l}-0.37^{* * *} \\
(0.08)\end{array}$ \\
\hline \multicolumn{5}{|c|}{ Feedstock Dummies (Reference=Coal) } \\
\hline Gas & $\begin{array}{l}-0.08 \\
(0.05)\end{array}$ & $\begin{array}{l}0.05 \\
(0.03)\end{array}$ & \begin{tabular}{|l}
$-0.10^{* *}$ \\
$(0.05)$
\end{tabular} & $\begin{array}{l}0.08 * * \\
(0.04)\end{array}$ \\
\hline Oil & \begin{tabular}{|l|}
$0.36^{* * *}$ \\
$(0.14)$
\end{tabular} & \begin{tabular}{|l}
$-0.21^{* *}$ \\
$(0.10)$
\end{tabular} & & \\
\hline Other & $\begin{array}{l}0.10 \\
(0.10)\end{array}$ & $\begin{array}{l}-0.06 \\
(0.06)\end{array}$ & $\begin{array}{l}0.09 \\
(0.10)\end{array}$ & \begin{tabular}{|l}
-0.08 \\
$(0.09)$
\end{tabular} \\
\hline Observations & \multicolumn{2}{|c|}{66} & \multicolumn{2}{|c|}{55} \\
\hline R-squared & \multicolumn{2}{|c|}{0.464} & \multicolumn{2}{|c|}{0.514} \\
\hline
\end{tabular}


Table 3: Ordered Probit Marginal Effects for Power Plant Sector Only

\begin{tabular}{|c|c|c|}
\hline \multirow{2}{*}{$\begin{array}{l}\text { Sample } \\
\text { Status }\end{array}$} & \multicolumn{2}{|c|}{ All } \\
\hline & Operational & Cancelled \\
\hline Variable & $\begin{array}{l}\text { Coefficient } \\
\text { (S.E.) }\end{array}$ & $\begin{array}{l}\text { Coefficient } \\
\text { (S.E.) }\end{array}$ \\
\hline Size & \begin{tabular}{|l}
$-0.11^{* *}$ \\
$(0.05)$
\end{tabular} & $\begin{array}{l}0.15^{* * *} \\
(0.06)\end{array}$ \\
\hline Size Squared & $\begin{array}{l}0.02^{* *} \\
(0.01)\end{array}$ & \begin{tabular}{|l|}
$-0.03^{* * *}$ \\
$(0.01)$
\end{tabular} \\
\hline Public Funding Dummy & $\begin{array}{l}-0.10^{* * * *} \\
(0.04)\end{array}$ & $\begin{array}{l}0.15^{* *} \\
(0.06)\end{array}$ \\
\hline Storage Site Confirmed & $\begin{array}{l}0.17^{* * *} \\
(0.05) \\
\end{array}$ & $\begin{array}{l}-0.25^{* * *} \\
(0.05)\end{array}$ \\
\hline Carbon Policy & $\begin{array}{l}-0.11^{* * *} \\
(0.04)\end{array}$ & $\begin{array}{l}0.15^{* * *} \\
(0.05)\end{array}$ \\
\hline Previous CCS Experience & \begin{tabular}{|l|}
$-0.13^{* *}$ \\
$(0.05)$
\end{tabular} & $\begin{array}{l}0.18^{* *} \\
(0.07)\end{array}$ \\
\hline \multicolumn{3}{|c|}{ Storage Dummies (Reference=Enhance Oil Recovery/Commerical) } \\
\hline Saline & \begin{tabular}{|l|}
$-0.08^{* *}$ \\
$(0.03)$
\end{tabular} & $\begin{array}{l}0.11^{* *} \\
(0.05)\end{array}$ \\
\hline Depleted Oil/Gas Reservoir & $\begin{array}{l}0.07 \\
(0.04)\end{array}$ & $\begin{array}{l}-0.10^{*} \\
(0.06)\end{array}$ \\
\hline \multicolumn{3}{|c|}{ Capture Process Dummies (Reference= Post-Combustion) } \\
\hline Pre-Combustion & \begin{tabular}{|l|}
$0.09 * *$ \\
$(0.04)$ \\
\end{tabular} & \begin{tabular}{|l|}
$-0.13^{* *}$ \\
$(0.05)$ \\
\end{tabular} \\
\hline Oxygen & $\begin{array}{l}0.03 \\
(0.05)\end{array}$ & $\begin{array}{l}-0.03 \\
(0.07)\end{array}$ \\
\hline \multicolumn{3}{|c|}{ Feedstock Dummies (Reference=Coal) } \\
\hline Gas & \begin{tabular}{|l|}
$-0.08^{* *}$ \\
$(0.04)$ \\
\end{tabular} & $\begin{array}{l}0.11^{* *} \\
(0.05) \\
\end{array}$ \\
\hline Oil & $\begin{array}{l}0.24^{* *} \\
(0.10) \\
\end{array}$ & $\begin{array}{l}-0.35^{* *} \\
(0.16) \\
\end{array}$ \\
\hline Other & & \\
\hline Observations & \multicolumn{2}{|c|}{42} \\
\hline R-squared & \multicolumn{2}{|c|}{0.485} \\
\hline
\end{tabular}


Table 4: Linear Probability Model under Different Dichotomous Dependent Variable Specifications

\begin{tabular}{|c|c|c|c|c|c|}
\hline \multirow{2}{*}{$\begin{array}{l}\text { Sample } \\
\text { Dependent Variable Specification }\end{array}$} & \multirow[t]{2}{*}{ No Planning } & \multicolumn{2}{|c|}{ All } & \multicolumn{2}{|c|}{ No Pilots } \\
\hline & & Optimistic & Pessimistic & Optimistic & Pessimistic \\
\hline Variable & $\begin{array}{l}\text { Coefficient } \\
\text { (S.E.) }\end{array}$ & $\begin{array}{l}\text { Coefficient } \\
\text { (S.E.) }\end{array}$ & $\begin{array}{l}\text { Coefficient } \\
\text { (S.E.) }\end{array}$ & $\begin{array}{l}\text { Coefficient } \\
\text { (S.E.) }\end{array}$ & $\begin{array}{l}\text { Coefficient } \\
\text { (S.E.) }\end{array}$ \\
\hline Size & \begin{tabular}{|l}
$0.71^{* * *}$ \\
$(0.25)$ \\
\end{tabular} & $\begin{array}{l}-0.15 \\
(0.12) \\
\end{array}$ & \begin{tabular}{|l}
$0.27^{* *}$ \\
$(0.13)$ \\
\end{tabular} & $\begin{array}{l}-0.17 \\
(0.12) \\
\end{array}$ & $\begin{array}{l}-0.08 \\
(0.13) \\
\end{array}$ \\
\hline Size Squared & $\begin{array}{l}0.19 * * * \\
(0.07) \\
\end{array}$ & $\begin{array}{l}0.04^{*} \\
(0.02) \\
\end{array}$ & \begin{tabular}{|l|l}
0.03 \\
$(0.02)$ \\
\end{tabular} & $\begin{array}{l}0.04^{*} \\
(0.02) \\
\end{array}$ & $\begin{array}{l}0.01 \\
(0.02) \\
\end{array}$ \\
\hline Public Funding Dummy & $\begin{array}{ll}-0.11 \\
(0.08) \\
\end{array}$ & $\begin{array}{l}-0.13 \\
(0.12) \\
\end{array}$ & \begin{tabular}{|l|}
-0.10 \\
$(0.10)$ \\
\end{tabular} & $\begin{array}{l}-0.19 \\
(0.11) \\
\end{array}$ & $\begin{array}{l}-0.02 \\
(0.10) \\
\end{array}$ \\
\hline Storage Site Confirmed & $\begin{array}{l}0.34^{* * *} \\
(0.12) \\
\end{array}$ & $\begin{array}{l}0.38^{* * *} \\
(0.10) \\
\end{array}$ & $\begin{array}{l}0.33^{* * *} \\
(0.10) \\
\end{array}$ & \begin{tabular}{|l|l}
$0.48^{* * *}$ \\
$(0.11)$ \\
\end{tabular} & $\begin{array}{l}0.24^{* *} \\
(0.10) \\
\end{array}$ \\
\hline Carbon Policy & \begin{tabular}{|l|l}
$-0.20^{* *}$ \\
$(0.10)$ \\
\end{tabular} & $\begin{array}{l}-0.11 \\
(0.10) \\
\end{array}$ & $\begin{array}{l}-0.26^{* * *} \\
(0.08) \\
\end{array}$ & \begin{tabular}{|l|l|}
$-0.20^{*}$ \\
$(0.12)$ \\
\end{tabular} & \begin{tabular}{l|}
-0.18 \\
$(0.11)$ \\
\end{tabular} \\
\hline Previous CCS Experience & $\begin{array}{l}0.07 \\
(0.16) \\
\end{array}$ & $\begin{array}{l}-0.20 \\
(0.15) \\
\end{array}$ & $\begin{array}{l}-0.17 \\
(0.13) \\
\end{array}$ & $\begin{array}{l}-0.26 \\
(0.17) \\
\end{array}$ & $\begin{array}{l}0.04 \\
(0.11) \\
\end{array}$ \\
\hline \multicolumn{6}{|c|}{ Storage Dummies (Reference=Enhance Oil Recovery/Commerical) } \\
\hline Saline & $\begin{array}{l}-0.13 \\
(0.10) \\
\end{array}$ & $\begin{array}{l}-0.15 \\
(0.11) \\
\end{array}$ & $\begin{array}{l}-0.01 \\
(0.01) \\
\end{array}$ & $\begin{array}{l}-0.07 \\
(0.11) \\
\end{array}$ & $\begin{array}{l}-0.06 \\
(0.10) \\
\end{array}$ \\
\hline Depleted Oil/Gas Reservoir & $\begin{array}{l}0.18 \\
(0.10) \\
\end{array}$ & \begin{tabular}{|l|}
0.15 \\
$(0.15)$ \\
\end{tabular} & $\begin{array}{l}0.13 \\
(0.12) \\
\end{array}$ & $\begin{array}{l}0.36^{* *} \\
(0.16) \\
\end{array}$ & $\begin{array}{l}-0.08 \\
(0.12) \\
\end{array}$ \\
\hline \multicolumn{6}{|c|}{ Capture Process Dummies (Reference=Post-Combustion) } \\
\hline Pre-Combustion & \begin{tabular}{|l}
-0.03 \\
$(0.14)$ \\
\end{tabular} & $\begin{array}{l}0.23^{* *} \\
(0.11) \\
\end{array}$ & \begin{tabular}{|l}
0.14 \\
$(0.14)$ \\
\end{tabular} & $\begin{array}{l}0.31 * * * \\
(0.11) \\
\end{array}$ & \begin{tabular}{|l}
0.13 \\
$(0.13)$ \\
\end{tabular} \\
\hline Oxygen & \begin{tabular}{|l|}
-0.14 \\
$(0.25)$ \\
\end{tabular} & \begin{tabular}{|l|}
0.05 \\
$(0.20)$ \\
\end{tabular} & $\begin{array}{l}-0.01 \\
(0.12) \\
\end{array}$ & \begin{tabular}{|l|}
0.26 \\
$(0.24)$ \\
\end{tabular} & $\begin{array}{l}-0.02 \\
(0.09) \\
\end{array}$ \\
\hline Industrial Seperation & \begin{tabular}{|l|l}
$0.35^{* *}$ \\
$(0.16)$ \\
\end{tabular} & \begin{tabular}{|l}
$0.35^{* * *}$ \\
$(0.12)$ \\
\end{tabular} & $\begin{array}{l}0.45^{* *} \\
(0.20) \\
\end{array}$ & $\begin{array}{l}0.50^{* * *} \\
(0.15) \\
\end{array}$ & $\begin{array}{l}0.49 * * \\
(0.21) \\
\end{array}$ \\
\hline NG Processing & \begin{tabular}{|l|}
$0.47^{* * *}$ \\
$(0.16)$ \\
\end{tabular} & \begin{tabular}{|l|}
$0.52^{* * *}$ \\
$(0.11)$ \\
\end{tabular} & $\begin{array}{l}.85^{* * *} \\
(0.12) \\
\end{array}$ & \begin{tabular}{|l|}
$0.62^{* * *}$ \\
$(0.12)$ \\
\end{tabular} & $\begin{array}{l}.89 * * * \\
(0.12) \\
\end{array}$ \\
\hline \multicolumn{6}{|c|}{ Feedstock Dummies (Reference $=$ Coal) } \\
\hline Gas & \begin{tabular}{|c|}
-0.02 \\
$(0.13)$
\end{tabular} & \begin{tabular}{|l}
-0.16 \\
$(0.11)$ \\
\end{tabular} & $\begin{array}{l}-0.08 \\
(0.13) \\
\end{array}$ & \begin{tabular}{|l}
$-0.25^{* *}$ \\
$(0.11)$ \\
\end{tabular} & $\begin{array}{l}-0.14 \\
(0.12) \\
\end{array}$ \\
\hline Oil & \begin{tabular}{|l|}
0.01 \\
$(0.08)$ \\
\end{tabular} & \begin{tabular}{|l|}
-0.29 \\
$(0.18)$ \\
\end{tabular} & \begin{tabular}{|l|}
0.23 \\
$(0.15)$ \\
\end{tabular} & & \\
\hline Other & \begin{tabular}{|l|}
0.18 \\
$(0.16)$ \\
\end{tabular} & \begin{tabular}{|l|}
0.15 \\
$(0.16)$ \\
\end{tabular} & \begin{tabular}{|l|}
0.15 \\
$(0.21)$ \\
\end{tabular} & \begin{tabular}{|l}
-0.01 \\
$(0.19)$ \\
\end{tabular} & $\begin{array}{l}0.28 \\
(0.22) \\
\end{array}$ \\
\hline Observations & 39 & 66 & 66 & 55 & 55 \\
\hline R-squared & 0.828 & 0.499 & 0.616 & 0.609 & 0.672 \\
\hline \multicolumn{6}{|c|}{$\begin{array}{l}\text { Notes: }{ }^{*}, * *, * * * \text { indicates } 10 \%, 5 \% \text {, and } 1 \% \text { statistical significance, respectively. The optimistic } \\
\text { dependent variable specification assumes that all projects that are being planned in our sample } \\
\text { become operational. The pesimistic dependent variable specification assumes that all projects that } \\
\text { are being planned in our sample become cancelled. }\end{array}$} \\
\hline
\end{tabular}


Table 5: Examples of Projects Cancelled or On Hold

\begin{tabular}{|c|c|c|c|c|c|c|c|c|c|c|c|c|}
\hline Industry & $\begin{array}{l}\text { Country/ } \\
\text { Region }\end{array}$ & $\begin{array}{l}\text { Project/ } \\
\text { Plant Name }\end{array}$ & $\begin{array}{l}\text { Size } \\
\text { (Mt CO2) }\end{array}$ & $\begin{array}{l}\text { Capture } \\
\text { Process }\end{array}$ & $\begin{array}{l}\text { Storage } \\
\text { Site }\end{array}$ & $\begin{array}{l}\text { Project } \\
\text { Status }\end{array}$ & $\begin{array}{l}\text { Cost } \\
\text { (US \$) }\end{array}$ & $\begin{array}{l}\text { Share of } \\
\text { Public } \\
\text { Funding }\end{array}$ & $\begin{array}{l}\text { Public } \\
\text { Funding }\end{array}$ & $\begin{array}{l}\text { Carbon } \\
\text { Policy }\end{array}$ & $\begin{array}{l}\text { Year of } \\
\text { Cancellation }\end{array}$ & Reason for Cancellation/ On hold \\
\hline Power & Alberta & Project Pioneer & 1 & Post & Saline/EOR & Cancelled & $1.90 \mathrm{E}+09$ & $41.00 \%$ & yes & yes & 2012 & Commercial viability \\
\hline CTL & Alberta & Swan Hills & 1.3 & Pre & EOR & On Hold & $1.50 \mathrm{E}+09$ & $18.00 \%$ & yes & yes & 2013 & Low gas price \\
\hline Power & Italy & Porto Tolle & 1 & Post & Saline & On Hold & $1.08 \mathrm{E}+09$ & $12.47 \%$ & yes & yes & Unknown & Legal issues \\
\hline Power & Poland & Belchatow & 1.8 & Post & Saline & Cancelled & Unknown & Unknown & yes & yes & 2013 & Lack of financing \\
\hline Power & Germany & $\begin{array}{l}\begin{array}{l}\text { Goldenbergwerk } \\
\text { (Huerth) }\end{array} \\
\end{array}$ & 2.6 & Pre & Saline & On Hold & $2.71 \mathrm{E}+09$ & Unknown & Unknown & yes & Unknown & Lack of financing \\
\hline Power & UK & Longannet & Unknown & Post & Saline & Cancelled & $1.65 \mathrm{E}+09$ & Unknown & yes & yes & 2011 & Lack of financing \\
\hline Power & UK & Hunterston & Unknown & Post & $\begin{array}{l}\text { Depleted } \\
\text { Gas }\end{array}$ & Cancelled & Unknown & Unknown & no & yes & 2012 & $\begin{array}{l}\text { Objections to project, withdrawal } \\
\text { of funding application }\end{array}$ \\
\hline Power & Germany & Janschwalde & 1.7 & $\begin{array}{l}\text { Oxy and } \\
\text { Post }\end{array}$ & $\begin{array}{l}\text { Depleted } \\
\text { Gas and } \\
\text { Saline }\end{array}$ & Cancelled & $1.50 \mathrm{E}+09$ & $12.00 \%$ & yes & yes & 2011 & Legal issues \\
\hline Power & Finland & FINNCAP & 1.25 & Post & $\begin{array}{l}\text { Depleted } \\
\text { Gas }\end{array}$ & Cancelled & $6.79 \mathrm{E}+08$ & Unknown & Unknown & yes & 2010 & Technological and financial risk \\
\hline Power & UK & Tilbury & Unknown & Post & Unknown & Cancelled & $1.00 \mathrm{E}+09$ & Unknown & no & yes & 2011 & $\begin{array}{l}\text { Change in company strategy: } \\
\text { Plant turned into biomass plant } \\
\text { instead }\end{array}$ \\
\hline Power & UK & Kingsnorth & Unknown & Post & $\begin{array}{l}\text { Depleted } \\
\text { Gas }\end{array}$ & Cancelled & $1.65 E+09$ & Unknown & yes & yes & 2010 & Lack of financing \\
\hline $\begin{array}{l}\text { Oil \& Gas } \\
\text { Processing }\end{array}$ & Netherlands & Green Hydrogen & 0.55 & Pre & EOR & On Hold & Unknown & Unknown & no & yes & 2013 & Lack of financing \\
\hline Power & Denmark & $\begin{array}{l}\text { Aalborg } \\
\text { Nordjylland }\end{array}$ & 1.8 & Post & Saline & Cancelled & Unknown & Unknown & no & yes & 2009 & $\begin{array}{l}\text { Commercial viability; Public } \\
\text { opposition }\end{array}$ \\
\hline $\begin{array}{l}\text { Oil \& Gas } \\
\text { Processing }\end{array}$ & Norway & Mongstad BKK & 1.2 & Post & Saline & Cancelled & Unknown & Unknown & yes & yes & 2013 & Commercial viability \\
\hline
\end{tabular}


